\title{
KEPEMILIKAN HAK ATAS TANAH DALAM KERANGKA POLITIK HUKUM AGRARIA NASIONAL
}

\author{
Widyarini Indriasti Wardani *
}

\begin{abstract}
The development of ownership of land rights in Indonesia develops in line with the developments of the State of Indonesia itself. In this case includes four periods that each period has a specificity related to the political history of the nation. The period is the period of the Kingdom period, the period of the nation's occupation period foreigners namely the Netherlands and Japan, the period of Independence, and the period after the release of Law No. 5/1960 (Basic Agrarian Law). With the enactment of UUPA (National Agrarian Law), the ownership of land rights in Indonesia only differentiates ownership of land rights for Indonesian citizens and for foreign nationals by recognizing the rights of individual land that is Property rights, Building Use Rights, Usage Rights, use rights and the right to lease and title to communal land that is ulayat right (inherited from customary law).
\end{abstract}

Key word: Ownership of Land Rights, Politics of Agrarian Law, National Agrarian Law

\section{PENDAHULUAN}

Tanah merupakan kebutuhan pokok manusia baik sebagai makhluk individu maupun makhluk sosial. Sebagai makhluk individu, tanah dibutuhkan manusia dari lahir untuk kehidupan ekonomis hingga meninggal dunia terutama bagi pemeluk agama-agama tertentu. Adapun sebagai makhluk sosial, tanah merupakan tempat berkumpulnya beberapa individu hingga membentuk kekerabatan ataupun suatu masyarakat kecil yang saling tergantung satu sama lain baik dalam masyarakat tradisional maupun masyarakat modern.

Tanah dibutuhkan manusia sebagai makhluk individu meliputi kebutuhan sosial, ekonomi dan religius. Kebutuhan sosial manusia terhadap tanah, karena manusia hidup bersama manusia lain sehingga manusia membutuhkan domisili,

* Widyarini Indriasti Wardani, Dosen Fakultas Hukum Universitas 17 Agustus 1945 Semarang dapat dihubungi Melalui Email : widoyrini. indriasti@gmail.com adapun domisili membutuhkan tanah. Kebutuhan ekonomi manusia terhadap tanah, karena manusia dalam memenuhi kebutuhan hidup meliputi mata pencahari an pertanian, perikanan, peternakan, perkebunan, maupun perindustrian. Adapun kebutuhan religius manusia terhadap tanah, dimulai manusia berumur 7 bulan dengan dimulainya manusia menginjakan kaki ke tanah, bahkan dalam tradisi jawa peristiwa tersebut perlu diadakannya upacara yang disebut "tedak siti". Kehidupan religius manusia berlanjut hingga sampai manusia meninggal dunia, kebutuhan manusia terhadap tanah setelah meninggal dunia yaitu dipergunakan untuk tanah kuburan. Hal ini dikarenakan lahan tidak bertambah, sedangkan jumlah manusia bertambah tidak sebanding dengan jumlah tanah maka tanah kuburan menjadi kebutuhan yang sulit diperoleh, yang pada akhirnya menjadi sangat komersil.

Berkaitan manusia sebagai makhluk individu dan makhluk sosial maka sangat berhubungan dengan kepemilikan hak atas 
tanah di Indonesia yang juga meliputi kepemilikan hak atas tanah secara komunal dan secara individu.

Kepemilikan hak atas tanah di Indonesia, secara kronologis dan historis terdiri darii dalam dua jenis kepemilikan yaitu sebagai berikut, Kepemilikan hak atas tanah secara komunal. Hak komunal masyarakat adat (communal bezitrecht) lazim disebut hak ulayat. Hak ulayat adalah hak atas tanah yang dimulai dengan membuka hutan dan dimiliki oleh persekutuan hukum. Pada prinsipnya setiap pemakaian bagian tanah komunal (gogol) sebagai individu (perorangan) harus tunduk kepaada penguasaan desa. Dalam hukum harta kekayaan, tanah komunal merupakan kepunyaan kepunyaan baik desa maupun gogol (pribadi), kecuali gogol meninggal kan hak pakainya guna kepentingan desa, sehingga menjadi tanah bengkok atau titisara.

Kepemilikan hak atas tanah secara perorangan (individu). Kepemilikan hak atas tanah didalam hukum adat pada awalnya terdapat beberapa penafsiran apakah secara perorangan atau komunal, namun setelah dikaji pada Tahun 1867 bahwa kepemilikan dan penguasaan perorangan atas tanah tidak ada di Jawa adalah keliru. Menurut Robert Van Niel, dikatakan bahwa kata "Yasa" sebuah kata yang lazim dipakai dalam bahasa Jawa mengacu kepada hak-hak penanam atas tanah yang baru dibuka ( hak kepemilikan perorangan), diartikan sebagai kepemilikan tanah. Istilah itu sebenarnya mengacu kepada pemanfaatan tanah yang akan mendapat imbalan tertentu, bukan merujuk kepada kepemilikan tanah yang dalam pengertian jawa adalah pemilik penguasa. Hak Yasa dikenal dalam masyarakat Jawa merupakan konsep hak perorangan atas tanah. Menurut Ter Haar5) hubungan kehidupan antara umat manusia yang teratur susunannya dan bertalian satu sama lain disatu pihak dan tanah dilain pihak, hubungan itu memunculkan hubungan pertalian hukum. Substansi hubungan tersebut, dinyatakan dalam beberapa pri nsip sebagai cermin kehidupan sebgai berikut:

- Tanah tempat mereka diam;

- Tanah yang memberi mereka makan;

- Tanah tempat mereka dimakamkan;

- Tanah tempat kediaman makhluk halus sebagai pelindung mereka besrta arwah leluhurnya;

- Tanah tempat meresap daya-daya hidup.

Menurut hukum adat hak milik atas tanah, berarti yang punya adat berlaku sekehendak hatinya dengan tanah tersebut sebagai yang dipertuan, dengan mem perhatikan beberapa pembatasan sebagai berikut:

- Harus memperhatikan hak ulayat sepanjang masih ada;

- Memperhatikan hak milik tanah yang ada disekitarnya;

- Menghormati aturan-aturan adat, seperti kewajiban untuk membiarkan tanahnya untuk menggembala selama tanahnya tidak dikerjakan, ditanam, dan dipagar;

- Menghormati aturan-aturan yang diadakan oleh negara.

Hubungan manusia dengan tanah berkaitan dengan kepentingan manusia terhadap tanah agar diakui oleh pihak lain bahwa seseorang memiliki hak terhadap tanah tersebut. Pengakuan oleh pihak lain terhadap tanah menurut hukum adat tidak dibuktikan secara yuridis, namun lebih secara defakto bahwa seseorang mendiami tanah tersebut secara terus menerus tanpa terdapat pihak lain yang merasa keberatan dengan keberadaan dan penguasaanya terhadap tanah tersebut. Dalam per kembangannya kepemilikan hak atas tanah di Indonesia selaras dengan perkembangan politik hukum nasional terdapat perubahan . Berkaitan dengan perubahan mendasar mengenai Kepemilikan hak atas tanah maka berikut permasalahan yang akan penulis sampaikan sebasgai berikut: 
Bagaimana perkembangan secara politishistoris kepemilikan hak atas tanah di Indonesia?

\section{PEMBAHASAN}

Sistem kepemilikan hak atas tanah di Indonesia (Hindia- Belanda) tidak dapat dilepaskan dari sejarah negara Indonesia yang dalam hal ini terbagi dalam empat periode, sebagai berikut:

1. Periode masa Jaman Kerajaan;

2. Periode masa Pendudukan asing (Belanda, Inggris, Jepang)

3. Periode masa Jaman Kemerdekaan.

4. Periode setelah keluarnya UUPA tahun 1960.

Keempat periode itu dapat dijelas kan sebagai berikut :

\section{Ad. 1 Periode masa Jaman Kerajaan}

Negara Indonesia yang dalam sejarahnya, nama Indonesia pertama kali diperkenalkan oleh orang Inggris bernama Goeorge Samuel Windsor dalam tulisannya berjudul "on the Leading Characteristics of the Papuan, Australian and MalayPolynesia" pada tahun 1850 di Journal of the Indian Archipelago and Eastern Asia (JIAEA), terbitan (Singapura) ${ }^{1}$ merupakan negara yang terbentuk sejak ratusan tahun silam. Dalam sejarah dimulainya adanya penguasaan, pemilikan dan penggunaan tanah diawali dengan pembukaan hutan oleh para penghuni Nusantara (nama Nusantara ada pada jaman Kerajaan Majapahit yang berasal dari kata Nusa dan antara yang berarti pulau-pulau diluar Majapahit). Pembukaan hutan tersebut dipergunakan sebagai lahan tempat tinggal disamping juga dipergunakan sebagai lahan mata pencaharian, misalnya pertanian, peternakan maupun perladangan yang dikelola secara sederhana. Dalam

1 (https://leendanusantara.wordpress.com/leg enda-nusantara/arti-nama-Indonesia-nusantaradan-asal-usulnya, hal 1, Selasa, 13.36 / 27-32018) perkembangannya, apabila pembukaan hutan tersebut dilaksanakan oleh suatu kelompok individu maka akan terbentuklah kelompok kecil yang pada akhirnya dibutuhkan seorang pemimpin. Pemimpin tersebut adalah sesorang yang dihormati, disegani dan kemungkinan juga ditakuti yang kemudian akan menjadi seorang pemimpin desa. Sebagai seorang pemimpin yang kemudian dinamai kepala Desa atau kepala adat akan menjalankan kewenangan nya sebagai pemimpin dengan membagibagi tanah yang telah dibuka kepada anakanak, demikian pula apabila terdapat para pendatang yang secara otomatis diharapkan tunduk terhadap aturan hukum yang berlaku di desa itu. Konsep tersebut adalah merupakan diawalinya pembentukan kepemilikan hak atas tanah yang terdiri dari dua jenis yaitu tanah komunal yang disebut Hak Ulayat (tanah ulayat) yang dikuasai dan dimiliki serta dipergunakan/ dimanfaatkan persekutuan hukum masyarakat adat. Adapun tanah kepemilik an perseorangan yang berasal dari pembagian tanah dari seorang pimpinan adat akan dikuasai, dimiliki secara perseorangan yang pemanfaatan dan penggunaannya diperuntukan untuk kepentingan individu/ keluarga kecil.

Adapun mekanisme masyarakat adat yang ingin membuka lahan baru adalah sebagai berikut:

a. Mabali. Yaitu merupakan pemberian tanda batas tanah oleh individu anggota masyarakat adat (seperti rotan diatas pohon;

b. Musyawarah dengan ketua adat. Meminta ijin pada ketua adat untuk membuka lahan yang telah ditandai

c. Membuka tanah. Membuka tanah dengan komunal (bergotong royong/ bersama-sama)

d. Mengusahakan (memperdayakan) yaitu menanami lahan, membangun rumah, berburu dll ${ }^{2}$

2 (https://leendanusantara.wordpress.com/leg enda-nusantara/arti-nama-Indonesia-nusantaradan-asal-usulnya, hal, 2 Jumat / 6-4-2018) 
e. Timbul hak Milik. Timbulnya hak milik tidak berarti mutlak kepemilikan individu anggota masyarakat adat.

Masyarakat asli (penduduk asli yang membuka hutan) apabila akan menggunakan lahan tanah baik untuk lahan pertanian ataupun untuk lahan tempat tinggal maka harus minta ijin kepada ketua adat dan membuat pernyataan kepada khalayak umum bahwa tanah tersebut tanah miliknya. Adapun warga masyarakat yang berasal dari wilayah lain yang bermaksud untuk menggunakan lahan tanah dari suatu wilayah yang bukan sebagai anggota masyarakat yang membuka hutan maka harus :

a. Berdekatan Izin kepada kepala adat;

b. dengan tempat tinggalnya (agar warga tersebut mampu bekerja dengan baik);

c. Memberikan 10 persen upeti (uang sewa);

d. Diberi waktu 3 kali panen, karena dikhawatirkan akan menjadi hak milik;

e. Bercocok tanam dengan tanaman yang berumur pendek ${ }^{3}$

Dalam perkembangannya Nusantara dipengaruhi adanya kebudayaan Hindu, dengan masuknya agama Hindu di Nusantara. Pengaruh agama Hindu sangat mempengaruhi sistem politik pemerintahan, pola kehidupan masyarakat/ kebudayaan dan pada akhirnya melahirkan Kerajaan-kerajaan di Nusantara. Sistem kerajaan melahirkan adanya feodalisme kehidupan baik dalam perilaku masyarakat, golongan di dalam masyarakat yang menciptakan strata sosial, maupun dalam sitem kepemilikan hak atas tanahnya.

Sistem feodalime melahirkan kekuasaan raja yang tak terbatas, sehingga rakyat sebagai kawulo raja tidak memiliki hak individu. Demikian pula terkait dengan penguasaan dan kepemilikan hak atas tanah dalam system feodalisme, dikarenakan raja yang memiliki kekuasaan yang tak terbatas maka Raja pun sebagai pemilik hakatas tanah. Rakyat sebagai kawulo raja tidak

3 Ibid hal 3 memiliki hak individu terhadap hakatas tanah, rakyat hanya memiliki hak memakai atau menggunakan hak atas tanah, baik sebagai lahan mata pencaharian maupun sebagai lahan tempat tinggal. Pemahaman tanah milik raja, tanah adalah kepunyaan para raja dan bangsawan ${ }^{4}$ dapat diartikan bahwa tanah selain sebagai asset bangsa dan alat produksi sepenuhnya dikuasai dan dimiliki oleh kerajaan sebagai penguasa, sedangkan rakyat sama sekali tidak memiliki hak bahkan untuk menjual kepada pihak lain. Dikarenakan tanah milik raja, maka dalam rangka tanah sebagai asset bangsa dan alat produksi yang boleh mengelola tanah hanya dua yakni :petani dan pengusaha. ${ }^{5}$ Rakyat hanya sebagai penggarap saja (Hanggaduh). :

\section{1). Petani :}

a. Harus membagi sebagian dari hasil pertanian

b. Rakyat memberikan tenaga untuk menggarap tanah.

2). Pengusaha :

a. Harus mempunyai perkebunan yang luas.

b. Pengusaha menyewakan hasil sewanya kepada petani;

c. Pengusaha peminta1/3 dari tanah yang disewa.

d. Pengelola harus mengelola tanah tersebut.

e. Penagih dari raja (bekel) mendapat $1 / 5$ dari hasilnya

System feodalisme juga terdapat pengaturan yang akan memberikan penghargaan kepada pihak-pihak yang berjasa bagi raja dengan memberikan sebidang tanah kepada orang-orang tersebut:

\section{Ad. 2 Periode masa pendudukan asing (Belanda, Jepang)}

Masa pendudukan pemerintah

\footnotetext{
5 Noor Fauzi Rachman, 2017, Petani dan Penguasa Dinamika Praktek Politik Agraria Indonesia, Insist press, Yogyakarta, hlm 15 6 Op cit hal $3 / 6$
} 
Belanda dimulai pada tahun 1596, kemudian tahun 1602 pendirian VOC dan pada tahun 1799 VOC pailit yang kemudian dibubarkan., Pada masa penddukan Belanda, tanah dipergunakan sebagai alat untuk memakmurkan bangsa Belanda dengan mengatur tanah untuk kepentingan pemerintah Belanda. Pemerintah Belanda menguasai wilayah Indonesia dengan cara menaklukan raja-radi Jawa, dengan system tanah miulik raja maka secara otomatis setelah raja ditaklukan, tanah dikuasai oleh pemerintah Belanda. Pada tahun 1808 .keadaan keuangan Pemerintah Hindia Belanda sedemikan buruk, sehingga Gubernur Jenderal Daendels banyak menjual tanah-tanah kepada pihak swasta. Keadaan ini terus berlangsung sampai muncul sistem pertanahan pemerintahan Hindia Belanda yang baru, dengan diundangkannya Agrarisch Wet 1870.

Sistem pertanahan pada zaman Pemerintahan Hindia Belanda, ditandai dengan dikeluarkan Agrarisch Wet 1870, setelah lebih dari 270 tahun pemerintah Belanda menduduki Hindia Belanda.Tanah adat yang memang sudah ada sebelum pemerintah Belanda menguasai wilayah Indonesia tetap diakui eksistensinya. Agrarisch Wet. 1870 mengatur bahwa kepemilikan hak atas tanah bersifat dualisme, artinya disamping tanah barat yang dikuasai golongan Eropa dan diatur dalam Buku II Burgelijke Wetboek, juga diakui tanah adat yang dikuasai golongan pribumi dan diatur dalam hukum adat secara tidak tertulis. Tanah barat meliputi: tanah eigendom, tanah opstal, tanah erfpacht, recht van gebruik (hak pakai), dan hak bruikkelen (hak pinjam pakai). Sedangkan tanah adat meliputi : tanah yasan, tanah norowito (tanah perorangan), tanah ulayat (tanah komunal).

Bagi petani penduduk asli umumnya berlaku hak-hak tanah menurut hukum adat, yang diperlakukan tidak sekuat (tidak memiliki bukti dokumen kepemilikan hak atas tanah) hak-hak barat, tak dapat jaminan negara selayaknya, sehingga hak-hak tanah menurut hukum adat itu tidak membawa hasil sepatutnya pada pertanian rakyat, yang tetap tinggal terbelakang dan lemah perekonomiannya. $^{6}$

Pada kondisi demikian tidak ada pembatasan kepemilikan hak atas tanah bagi golongan Eropa terutama bagi penguasa Belanda, seorang Gubernur Jenderal dapat menguasai hampir seluruh wilayah. Agrarisch Wet 1870 telah memberikan keuntunganyang besar bagi golongan Eropa dan merugikan golongan pribumi yaitu dengan adanya asas Domein Verklaring. Asas Domein Verklaring adalah asas yang menegaskan bahwa seseorang yang tidak dapat membuktikan tanahnya tanah eigendom, maka menjadi tanah negara. Pihak yang dapat membuktikan tanahnya adalah tanah eigendom hanyalah golongan Eropa, maka hal ini menjadi sarana yuridis kepemilikan hak atas tanah bagi golongan Eropa khususnya penguasa kolonial menguasai tanah-tanah rakyat. Tanah-tanah rakyat tersebut kemudian dapat disewakan kepada pengusahapengusaha partikelir/ swasta golongan Eropa, Cina, Arab, dan India untuk dapat menguasai perkebunan-perkebunan di Hindia Belanda.Golongan-golongan masyarakat tersebut yang kemudian menjadi tuan-tuan tanah.

Pada masa Negara Belanda dibawah pendudukan Perancis (dibawah Kaisar Napoleon Bonaparte ), Hindia Belanda dikuasai oleh Inggris yang berpusat di Bengkulu juga menduduki Singapura dan Malaysia (1811-1815) dibawah Gubernur Jenderal Thomas Stamford Raffles. Pendudukan Inggris ini memberikan sumbangan yang sangat berharga dalam bidang pertanahan di Hindia Belanda. Raffles mewajibkan rakyat untuk membayar pajak, sehingga muncul adanya letter D/C sebagai bukti pembayaran pajak bagi tanah milik adat. Sebelum adanya

6 R. Roestandi Ardiwilaga, 1960, Hukum Agraria Indonesia, Masa baru, Jakarta, hlm 113 
letter $\mathrm{D} / \mathrm{C}$, tanah-tanah yang dikenakan pajak hanya tanah-tanah milik golongan Eropa. Adanya letter D/C bagi golongan pribumi ini mengakibatkan bahwa tanah hak milik adat individual keberadaannya diakui dengan ditandai pathok, walaupun hal ini sebenarnya lebih menekankan pada pemasukan pajak bagi pemerintah. Kebijakan pajak terhadap hak milik adat kemudian diteruskan oleh pemerintah Belanda, karena memberi keuntungan pemasukan keuangan bagi pemerintah. Kondisi ini sampai sekarang masih berlaku dan menjadi satu-satunya bukti kepemilikan tanah bagi hak milik tanah yang belum bersertifikat.

Masa pendudukan pemerintah Jepang selama tiga setengah tahun tidak terdapat perubahan dalam sistem pertanahan.Politik Agraria pada jaman penguasaan Jepang, dipusatkan pada penyediaan bahan makanan untuk perang.Tanah-tanah partikelir, oleh pemerintah pendudukan Jepang dimasuk kan dalam urusan pemerintah dengan membentuk Kantor Urusan Tanah Partikelir. Yang disebut Siryooti Kanrikoosya, ${ }^{7}$ hal ini berdasarkan Undang undang Balatentara Dai Nippon no 171 Juni 26002 tahun 1942 yang dihubungkan dengan Osamu Seirei no 2 tahun 1943 yang menyebutkan "sekalian tanah partikelir menjadi kepunyaan Balatentara Dai Nippon sejak waktu undang-undang ini berlaku . Dalam beberapa kasus terdapat tanah-tanah rakyat yang diambil alih oleh pemerintah Jepang dalam rangka penyediaan makanan untuk perang.

\section{Ad 3 Periode masa Zaman Kemerdekaan}

Masa kemerdekaan pada tahun 1945, dengan diundangkannya UUD 1945, maka secara tegas pengaturan di bidang agraria

7 Muhammad Tauchid, 1952, Masalah Agraria Sebagai Masalah Penghidupan dan Kemakmuran Rakyat Indonesia, Bagian II, Tjakrawala, Jakarta, hlm 8, sebagaimana dikutip Noor fauzi Rochman, Op cit, hlm 49 termaktub dalam Pasal 33 ayat (3):

Bumi, air dan seluruh kekayaan alam yang terkandung didalamnya dikuasai oleh negara dan dipergunakan sebesar-besarnya untuk kemakmuran rakyat.

Landasan hukum tersebut diatas menunjukan bahwa tanah merupakan faktor utama pendukung kehidupan dan kesejahteraan bagi masyarakat, sehingga konsep hak kepemilikan menentukan susunan kehidupan dalam suatu Negara. ${ }^{89}$

Negara mengatur bahwa Negara sebagai subyek hukum untuk melakukan perbuatan hukum terhadap sumber daya alam yaitu bumi, air, serta kekayaan alam yang terkandung didalamnya.Negara dalam melakukan perbuatan hokum semata-mata untuk kepentingan rakyat Indonesia dengan memanfaatkan sumber daya alam semaksimal mungkin dan sebesar-besarnyauntuk kemakmuran rakyat. Pemanfaatan dan penggunaan tanah oleh Negara harus secara adil, transparan, dan prduktif dengan mengutamakan hakhak rakyat setempat (hak ulayat dan masyarakat adat), berdasarkan tata ruang wilayah yang seimbang.

Periode tahun 1945 sampai dengan tahun 1960 kepemilikan hak katas tanah masih adanya dualisme hokum untuk hak atas tanah barat dan tanah adat. Periode terebut terdapat beberapa peraturan yang dikeluarkan oleh pemerintah berupa: penguasaan, penetapan dan pengawasan terhadap tanah-tanah milik Negara, misalnya tanah perkebunan, tanah-tanah perdikan dan tanah-tanah partikelir (tanahtanah yang dikuasai tuan tanah) yang diambil alih penguasaannya kepada Negara Indonesia Kebijakan kebijakan pemerintah menunjukan adanya pengambilalihan tanah tanah Eropa, tanah milik tuan tanah yang

8 Boedi harsono, Hukum Agraria Indonesia, Sejarah Pembentukan Undangundang pokok agrarian isi dan pelaksanaannya jilid 1, Djambatan, 1994, hlm 83

9 Aslan Noor, 2006, Konsep Hak Milik Atas Tanah Bagi Bangsa Indonesia ditinjau dari Ajaran Hak Asasi Manusia, Mandar maju, Bandung, hlm 8. 
dikuasai oleh terwujud melalui beberapa peraturan sebagai berikut;

a. Mengenai eksistensi desa-desa perdikan yaitu tanah-tanah yang setengahnya dikuasai para Kepala desa dan keluarganya sebagai sumber pendapatan , karena tidak sesuai dengan cita-cita Demokrasi untuk revolusi Indonesia dikeluarkan UU No 13/1946untuk diambil alih oleh negara dan dibagi-bagi kan kepada para petani penggarap ataupun penyakap.

b. UU No 13 tahun 1948 yang mencabut Ketentuan VGR (Vorstenlandsch Grondhuur Reglement) yang mengatur hak-hak konversi yaitu ketentuan pengusaha untuk mendapatkan tanah meliputi :

- Atas ketentuan "beschiking atas keputusan raja

- Secara menyewa dari rakyat dan

- Secara menyewa dari raja.

c. Keputusan pemerintah tanggal 8 April No I tahun 1949 dikembalikannya sebanyak 48 bidang tanah partikelir sebanyak 469.506 ha yang terletak di daerah Cimanuk.

d. Dikeluarkannya UU Darurat No I tahun 1952 mengenai Pengawasan pemindah an hak atas tanah dan barang-barang tetap lainnya yang bertakluk pada hokum Eropa, pada dasarnya harus ada izin dari Menteri.

e. Kemudian terkait dengan pengawasan pemindahan hak atas tanah perkebunan dikeluarkan UU No 28 tahun 1956 dan PP No 35 tahun 1957yang diubah PP no 21 tahun 1959 yang pada dasarnya setiap pemindahan ha katas tanah-tanah Eropa mis eigendom dan hak kebendaan lainnya harus izin Menteri Pertanian

f. Dikeluarkan UU No 1 tahun 1958 yang mengatur pengembalian tanah-tanah partikelir sejumlah 12.000 ha tanah partikelir meliputi Di Jawa 29.000 ha, di Sulawesi 2500 ha. Disamping itu dikembalikan kepada Negara, di Jakarta raya 1.360 ha, semarang, 355 ha,
Surabaya 786 ha apabila dijumlah, 2 . 501 ha.

g. Dalam hal pemindahan hak karena jual beli tanah, kepala desawajib diikut sertakan sebagai saksi dan yang mengetahui berdasarkan Keputusan MA (Yurisprudensi) No 4/K/RUP/ $1958 .^{10}$

Adapun kepemilikan hak atas tanah individu pada periode ini, berdasarkan pasal II Aturan Peralihan UUD 1945 masih menggunakan peraturan zaman Hindia Belanda Yaitu Agrarisch Wet 1870 dengan asas Nasionalisme. Kepemilikan hak-hak atas tanah terdapat tanah berupa tanahtanah eropa, dan tanah-tanah adat. Pemindahan kepemilikan hak atas tanah dengan menggunakan hukum barat dan hukum adat terkait dengan tanah barat atau tanah adat.

\section{Ad 4. Periode setelah keluarnya UUPA tahun 1960}

Pada tahun 1960 pemerintah Indonesia mensahkan Undang Undang No 5 tentang Peraturan Dasar Pokok-pokok Agraria (Undang Undang Pokok-Pokok Agraria/ selanjutnya disingkat dengan UUPA), yang sekaligus mencabut Agrarisch Wet 1870.UUPA berdasarkan landasan Idiil Pancasila dan UUD 1945. Sunarjati Hartono menegaskan bahwa landasan Idiil dari hak milik adalah Pancasila dan UUD 1945, jika demikian maka landasan idiil tersebut bukan hanya didasari salah satu sila atau salah satu pasal dari UUD 1945, akan tetapi wajib didasari atas Pancasila sebagai satu keseluruhan dan berkaitan dengan UUD 1945 sebagai satu keseluruhan yang sistematis (bukan hanya diambil satu pasalnya saja). Hal ini dapat ditegaskan UUPA landasan Idiilnya Pancasila dan UUD 1945 sebagai satu keseluruhan, dan bukan hanya pada satu pasalnya saja, namun Pasal 33 ayat (3) menegaskan keberadaan negara dalam

10 Ibid, Boedi Harsono, Hal 76 Sd 97 
mengatur bidang agraria.

Penekanan negara mempunyai hak menguasai terhadap bumi, air dan ruang angkasa lebih menegaskan bahwa negara tidak mempunyai hak untuk memiliki terhadap bumi, air dan ruang angkasa, termasuk kekayaan alam yang terkandung didalamnya, maka negara tidak dapat menjual atau menggadaikan terhadap bumi air dan ruang angkasa, termasuk kekayaan alam yang terkandung didalamnya. Hal ini merupakan perwujudan Pasal 33 ayat (3)UUD 1945 yang telah menetapkan bahwa bumi, air dan seluruh kekakayaan yang terkandung didalamnya dikuasai oleh negara dan dipergunakan sebesar-besarnya untuk kemakmuran rakyat. Pasal 33 ayat (3) UUD 1945 tersebut memberi kewenangan kepada negara sebagai subyek hukum yaitu negara melakukan perbuatan hukum terhadap sumber daya alam (bumi, air dan kekayaan alam yang terkandung didalam nya). Kewenangan yang diberikan oleh negara harus didasarkan pada prinsip yang fundamental, yakni :

a. Asas tanggung jawab negara (state liability);

b. Asas legalitas, yang memberikan jaminan keadilan, kepastian, dan perlidungan;

c. Asas keberlanjutan (sustainability) yang mengakui dan menyadari bahwa sumber daya itu bersifat terbatasdan adanya jaminanuntuk dapat dinikmati untuk generasi kini dan generasi yang akan datang;

d. Asas manfaat, baik secara ekonomi maupun sosial;

e. Asas subsidiaritas, yakni pemberian kepercayaan dan kewenangan kepada sub unit pemerintahan yang lebih rendah melalui sistem desentralisasi yang demokratis. ${ }^{11}$

Selanjutnya keberlakuan UUPA dalam pasal 5 nya secara tegas menyatakan bahwa UUPA berdasarkan Hukum Adat,

11 Muhamad Ilham Arisaputra, 2015, Reforma Agraria Indonesia, Sinar Grafika, Jakarta, hlm 93 yang berarti sebagai sumber utama UUPA adalah hukum adat. (hukum adat yang disaneer/ disaring).

Pengaturan pemanfaatan dan pengguna an tanah oleh negara telah disebutkan dalam ketentuan pasal 2 ayat (2)UUPA, yaitu:

1. Mengatur dan menyelenggarakan peruntukan, penggunaan, persediaan dan pemeliharaan bumi, air dan ruang angkasa tersebut;

2. Menentukan dan mengatur hubungan hukum antara orang-orang dengan bumi, air dan ruang angkasa;

3. Menentukan dan mengatur hubungan hukum antara orang-orang dan perbuatan hukum yang mengenai bumi, air, dan ruang angkasa.

Pasal 2 ayat (4) nya menegaskan bahwa :

Hak menguasai dari negara tersebut diatas pelaksanaannya dapat dikuasakan pada Pemerintah Daerah dari masyarakat Hukum Adat, sekedar diperlukan dan tidak bertentangan dengan kepentingan nasional menurut Peraturan Pemerintah.

Setelah kemerdekaan Indonesia pada tahun 1945 dan kemudian diundangkan Undang Undang Pokok Agraria tahun 1960, kepemilikan hak atas tanah bersifat individual tetap diakui dan diatur, disamping mengakui adanya hak Ulayat (kepemilikan hak atas tanah secara komunal) sepanjang tidak bertentangan dengan kepentingan umum dan tidak boleh membuka hak ulayat baru. Kepemilikan hak atas tanah menurut UUPA berdasarkan hukum adat, dalam hal ini pada pasal 6 UUPA ditegaskan bahwa hak atas tanah berfungsi sosial. Berfungsi sosial diartikan bahwa sepanjang kepentingan umum menghendaki maka kepentingan individu harus dikesampingkan. Jenis hak atas tanah dan kepemilikan hak atas tanah yang dapat dimiliki secara individu, harus dapat dibuktikan secara defakto dan yuridis dalam bentuk sertifikat hak atas tanah. Diatur di dalam UUPA Pasal 16 adalah sebagai berikut :

(1) Hak-hak atas tanah sebagai yang 
dimaksud Pasal 4 ayat (1) ialah:

a. Hak milik;

b. Hak guna usaha;

c. Hak guna bangunan;

d. Hak pakai;

e. Hak sewa;

f. Hak membuka hutan;

g. Hak memungut hasil hutan,

h. Hak-hak yang tidak termasuk dalam hak-hak tersebut di atas yang akan ditetapkan dengan undang-undang serta hak-hak yang sifatnya sementara sebagai yang disebutkan dalam Pasal 53.

(2) Hak-hak atas air dan ruang angkasa sebagai yang dimaksud dalam Pasal 4 ayat (3) ialah:

a. Hak guna-air;

b. Hak pemeliharaan dan penangkapan ikan,

c. Hak guna-ruang angkasa.

\section{KESIMPULAN}

Perkembangan kepemilikan hak atas tanah di Indonesia berkembang sejalan dengan perkembangan dari Negara Indonesia sendiri.Dalam hal ini meliputi 4 periode yang masing-masing periode memiliki kekhususan terkait dengan masa sejarah politik hukum bangsa Indonesia. Disamping itu masing-masing periode tersebut akan berakibat pada system kepemilikan hak atas tanah dikarenakan mempengaruhi culture budaya bangsa dan politik bangsa asing yang masuk di Indonesia berpengaruh besar. Hal ini menimbulkan bangsa/rakyat Indonesia belum dapat menikmati kekayaan sumber alam yang luar biasa dari Indonesia. Dalam hal ini penulis rangkum sebagai berikut :

a. Masa periode awal sebelum zaman kerajaan kepemilikan hak atas tanah sangat bersifat komunal ,hakatas tanah individu lemah.

b. Masa periode zaman Kerajaan yang bersifat feodalisme sangat mengecilkan hakrakyat, dengan ketentuan "tanah milik raja"

c. Masa zaman pendudukan bangsa asing (Belanda dan Jepang), semakin mengecilkan hak rakyat sebagai pemilik tanah, dengan tanah-tanah dikuasai bangsa asing.

d. Masa periode zaman kemerdekaan dari tahun 1945 sampai dengan 1960, politik Negara mengeluarkan banyak peraturan dalam rangka pengembalian tanahtanah yang dikuasai bangsa asing dan tuan-tuan tanah.

e. Masa periode setelah keluarnya UU No. 5 tahun 1960 yang disebut Undang Undang Pokok Agraria (UUPA) sampai sekarang.Kepemilikan ha katas tanah tidak ada lagi pembagian golongan penduduk, yang dibedakan dalam pemilikan hak atastanah untukwarga Negara Indonesia dan warga Negara asing. Adapun ha katas tanah untuk individu adalah Hak Milik, Hak Guna Bangunan, hak guna usaha, hak pakai, hak sewa, disamping juga diakui hak atas tanah komunal yaitu hal ulayat dengan ketentuan masih ada, dan pemakaiannya tidak bertentangan dengan kepentingan umum dan peraturan yang lebih tinggi.

\section{Daftar Pustaka}

Aslan Noor, 2009, Konsep Hak Milik Atas Tanah Bagi Bangsa indonesia, ditinjau dari Ajaran Hak Asasi Manusia, Mandar Maju, Bandung.

Budi Harsono, 1999, Hukum Agraria Indonesia, Sejarah Pembentukan Undang-Undang Pokok Agraria, Isi dan Pelaksanaanya. Djambatan, Jakarta.

B Ter Haar Bzn, 1994, Asas-asas dan Susunan Hukum Adat, $\{$ terjemahan Soebakti 
Poesponoto), Pradnya Paramita, Jakarta.

Carl Joachim Frederich, 2004, Filsafat hukum Perspektif Historis, Nuansa dan NusaMedia, Bandung.

CFG Sunarjati Hartono, 2009, Politik Hukum Menuju Pembangunan Ekonomi, Badan pembinaan Hukum Nasional, Departemen Hukum dan HAM Republik Indonesia.

Mahfudz MD, 2009, Politik Hukum di Indonesia, Rajawali Pers, Jakarta.

Maria, S.W., Soemardjono,, 2008, Tanah Dalam Perspektif Hak Ekonomi, Sosial dan Budaya, Kompas, Jakarta

-1005, Kebijakan Pertanahan Antara Regulasi dan Implementasi, Kompas, Jakarta.

Miriam, Budiardjo, 1996, Dasar-dasar Ilmu Politik, Gramedia Pustaka Utama, Jakarta.
Muhammad Ilham Arisaputra, 2015, Reforma Agraria Indonesia, Sinar Grafika, Jakarta.

Satjipto Rahardjo, 2010, Ilmu Hukum, Alumni, Bandung.

Supriadi, 2015, Hukum Agraria, Sinar Grafika, Jakarta.

Suriansyah Murhaeni, 2008, Kewenangan Pemerintah Daerah mengurus Bidang Pertanahan, LaksBang, Surabaya.

Widyarini Indriasti Wardani, 2015, Pengantar Hukum Indonesia, Fakultas Hukum UNTAG Semarang.

(https://leendanusantara.wordpress.com/le $g$ enda-nusantara/arti-namaIndonesia-nusantara-dan-asalusulnya, diunduh, Selasa 27-32018)

UUD 1945 berikut Amandemennya.

Undang-Undang No 5 Tahun 1960 tentang Peraturan Dasar Pokok-pokok Agraria 